\title{
DR. GALLAND'S ACCOUNT OF THE HALF-BREED TRACT.
}

Dr. Isaac Galland was one of the earliest settlers of Lee county, Iowa, and among his other enterprises he published the Iowa Advocate and Half-Breed Joumal, the first one of which was issued August 16th, 1847, under the following prospectus :

\section{PROSPECTUS OF THE IOWA ADVOCATE AND HALF-BREED JOURNAI.}

Will be published about the first and fifteenth of each month. The publisher proposes to devote a portion of its columns to the dissemination of facts connected with the past history, present condition and future prospects of the empire county of Lee, in the new state of Iowa.

In politics the Advocate will be independent, but not neutral. At our hands fraud, dishonesty, crime and oppression shall receive no quarter. For the tampering demagogue, the trafficing politician, the apostatising renegade, the patron of injustice, the protector of villainy, the perpetrator of malice, the inventor of fraud, and the propagator of calumny-the destroyers of private comfort, and public tranquility, we have a "scourge of scorpions". which shall be unceasing and vigorously applied. No matter how exalted the station in society, or with what official dignity panoplyed-these shall not protect the offender from public exposure. To the interests of literature and science, the supremacy of law, and the impartial administration of justice, we ghall endeavor to contribute our humble support.

I. Galland,

Nashville, Iowa, Aug. 9, 1847.

The extent of the circulation of this paper is at the present time unknown. The Historical Department through $\mathrm{Mr}$. Washington Galland, a son of Dr. Galland, has been able to acquire four numbers of the first volume. The entire series is devoted almost exclusively to an account of the Half-breed Tract and litigation therewith. Dr. Galland who was one of the litigants was closely associated both with the 
Government and Indian makers of the treaty before he became interested pecuniarily in the tract. It is deemed worth while to reproduce in toto the account which Dr. Galland published August 16, September 1, September 22, and December 15, 1847.

\section{HISTORY OF THE SAUK \& FOX HALF-BREED RESERVATION. NUMBER ONE.}

On the 4th day of August A. D. 1824, the United States by treaty with the Sauk and Fox nation or tribes of Indians, purchased all the lands lying within the limits of the Northern boundary of the State of Missouri and extending the North boundary line from the Desmoines river at the Northeast corner of the said state on the same latitude to the Mississippi river through a district of country not included within the jurisdiction of the State of Missouri; it was provided in the last clause of the first article in that treaty, as follows, to-wit:

"It being understood that the small tract of land lying between the rivers Desmoines and Mississippi and the section of the above line between the Mississippi and the Desmoines is intended for the use of the half-breeds belonging to the Sac and Fox nations, they holding it, however, by the same title and in the same manner that other Indian titles are held."-Ratified January 18, 1825.

Application was afterwards made to the office of Indian affairs in the War Department by the half-breeds to have these lands laid off and divided among them and in view of accomplishing this object, Congress appropriated two thousand dollars.

In 1832 Maj. Spriggs surveyed the tract under a contract with Gov. Clark, Superintendent of Indian Affairs, at St. Louis, Mo., and reported the same to the Department. Soon after this the Government proposed to purchase the lands but the proposal was rejected.

In June, 1834, Congress passed the act hereinafter recited, relinquishing the reversionary right of the Government in said lands. The half-breeds and their vendees still supposed that the Government was slowly progressing in the partition and division of these lands among the rightful claimants until some time in August, 1836, the following unexpected and unwelcome intelligence contained in the following correspondence, was published in the Missouri Republican, in St. Louis, to-wit:

\section{[A COPY]}

\section{SAC AND FOX HALF-BREED LANDS.}

Notice is hereby given to claimants to the land lying between the rivers Desmoines and Mississippi, reserved by the treaty concluded on the 4th of August, 1824, with the Sacs and Foxes, for the use 
of the half-breeds of said tribes, that all measures having in view a division of said lands among the claimants, through the agency of this office have ceased by order of the War Department and that no further action on subjects connected with said land will be had by it.

Subjoined hereto is a copy of the communication from the Department countermanding further proceedings by this office relative to the land in question. And for the information and guidance of claimants a copy of the act of the 30th June, 1834, adverted to in the communication, is also appended.

(Signed) WM CLARK, Superintendent of Indian Affairs.

Superintendency of Indian Affairs,

St. Louis, August 5, 1836.

\section{[A COPY]}

Department of War, Office Indian Affairs. April 23, 1836.

Sir:-The United States having relinquished by the act of 30 th June, 1834, the reversionary interest of the lands of the Sacs and Foxes half-breeds between the rivers Desmoines and Mississippi and it having been represented to the Department that the half-breeds object to any agency of the Government in laying off and dividing the said lands reserved for their use, you will [. ]* fore given to you on the subject, hereby countermanded and no further proceedings will be had by the Government in laying off and dividing the lands.

Very respectfully, your humble s'v't,

(Signed) Elbert Herring.

Gex. Wa. Clakk, St. Louis, Mo.

An Act to relinquish the reversionary interest of the United States in a certain Indian reservation lying between the rivers Mississippi and Desmoines.

Sec. 1st. Be it enacted by the Senate and House of Representatives of the United States of America in Congress assembled That all right, title and interest which might accrue or revert to the United States to the reservation of land lying between the rivers Desmoines and Mississippi which was reserved for the use of the half-breeds belonging to the Sacs and Fox nations now used by them or some of them under a treaty made and concluded between the United States and the Sacs and Fox tribes or nations of Indians at Washington

*The four numbers of the Iowa Advocate and Half-Breed Journal in our files are the only copies known to exist. Tne paper is worn in creases and brackets indicate unelecipherable words.-Ed. 
on the fourth day of August in the year one thousand eight hundred and twenty-four, be and the same are hereby relinquished and vested in the said half-breeds of the Sacs and Fox tribes or nations of Indians who at the passage of this act are under the reservations in the said treaty entitled by the Indian title to the same with full power and authority to transfer their portions thereof by sale, devise, or descent according to the laws of the State of Missouri.

Approved June 30th, 1834.

It will be perceived by the foregoing order of Mr. Herring, Commissioner of Indian Affairs to Gov. Clark, Superintendent, etc., that the War Department continued to exercise exclusive jurisdiction over this Indian reservation up to the $23 \mathrm{~d}$ day of April, 1836, but the act of Congress relinquishing it to the half-breed Indians was passed June 30, 1834, hence the Government of [. $]$ exercised jurisdiction for nearly two years after the relinquishment, it is therefore, clear that the general Government did not regard the relinquishment of reversionary interest as an abandonment of jurisdiction.

Mr. Herring in very express terms assigns the reason why the Department countermanded their orders for laying off and dividing the lands among the half-breeds; he says:

"It having been represented to the Department that the half-breeds object to any agency of the Government in laying off and dividing said lands reserved for their use, you will therefore consiter the instructions heretofore given to you on this subject hereby countermanded," \&c.

The following letter from Gov. Clark to us, will explain the course adopted by the Department at that time and to some ex[ of the Government in reference to this land.

Superintendency of Indian Affairs, St. Louis, January 7, 1834.

Doct. I. Galland:

Sir:-Your letter of the 12th ult. on the subject of the claim of Mary Tolman, formerly Mary Duque, and the accompanying deposition of Show-a-no-quoh, a Fox woman, in its support, have been received and shall be filed away for the necessary action at the proper time.

The copy of a certificate from certain chiefs and principal men - of the Sac and Fox Indians as to the blood of St. Jean's children stated by you to have been also forwarded with your letter has not reached this office nor has the deposition which you mention as having transmitted, proving the heirs of St. Jean to have been of Sac descent come to hand. Should it be the wish of those in. terested to file these papers in this office let them be forwarded as early as practicable. And I would recommend that all claims 
forwarded be supported by the deposition of the claimants and by such other testimony as is available; the depositions should be taken before a justice of the peace, certified to be such by a clerk of some court of record. Mere unauthenticated copies of certificates or reference to individuals will most likely not be considered sufficient when the claims come to be decided on.

I beg leave further to remark that the object now in view is to give an opportunity to all who consider themselves justly entitled to lands as half-breeds under the Sac and Fox treaty of 4th August, 1824, of presenting their claims with the evidence in their support. The time and mode of distribution of the lands, as well as the nature of the title to be conveyed, have not I am 'inclined to think, been yet determined, but as the lands are surveyed the subject will most probably receive an early attention at Washington.

I have the honor to be, respectfully,

Your obedient s'v't,

WM. Clare.

\section{NUMBER TWO.}

In presenting to.our readers the following letters from the chiefs of the Sauk and Fox Indians to Gov. Clark we would remark that the list of names, ages, residence and parentage of the half breeds referred to, we may hereafter publish.

To General William Clark, Superintendent of Indian Affairs at St. Louis:

Father:-Last year whilst at Prairie du Chien we wrote a letter to our Great Father, the President of the United States, requesting him to have the land surveyed which was given to our relations, the half-breeds of our nations at the treaty made at Washingtion City, on the 4th day of August, 1824; hut as yet we have received no answer. Father, above are the names and ages of the halfbreeds of our nation who were in existence when we made that treaty and to whom we gave that tract of land and to none others whatsoever. Father; we wish you to interest yourself for our relations the half-breeds of our nations who are mentioned on this list to have their lands surveyed and equally divided, it beins perfectly understood at the before mentioned treaty that Maurice Blondeau was to have his choice of any place in the said tract of land so granted. Father; we wish you to remove all the white people now on that tract of land which we intended for the use of the half-breeds of our nations and not to allow any white pecple of any descripiton to settle and live on that land except a father, a husband or wife of any of the half-breeds or any agent appointed by the President. Father; we wish you to prevent any white per- 
sons or half-breeds from keeping any spirituous liquors for sale on any part of the above mentioned tract of land, on any account, whatever but if [

I white people or half-breeds who wish to sell goods to Indians or others, we can have no objection to their being allowed to remain anywhere on the tract of land, provided you choose to give them a license.

Perchapaho," his $\mathrm{X}$ mark.

Pishkeenanie, his $\mathrm{x}$ mark.

Wabalalow, his $\mathrm{x}$ mark.

Taimah, his $\mathrm{X}$ mark.

Seokuk," his $\mathrm{X}$ mark.

Mukkopaum, his $\mathrm{X}$ mark.

The above mentioned chiefs also request that Lalott (Keokuk's mother) a half-breed, shall have a share in the above mentioned land, that is to say, that Thomas Abbott's and Isalott's land may join together at a place called the orchard at the head of the Des Moine rapids.

Explained and signed before me this 9th day of June, 1830, at Rock Island.

\section{(Signed) Thomas Forsyth, Indian Agent for Sac and Fox Indians.}

In presenting to our readers the following extract from a printed circular which we addressed to the claimants of these lands more than eight years ago we shall exhibit to the public our own position and views at that time on this subject. Great changes have taken place in our population since, but it will be readily perceived that no great change has taken place to advance the interest or to quiet the title to these lands. The schemes of judicial swindling and legislative robbery commenced about ten years ago-we believed at that time as we do now that the Territorial government had no jurisdiction in the case, unless applied to by the owners of the reservation for authority to choose arbitrators to lay off and divide said lands among the persons who might prove their rights to the same-that such proofs and the other proceedings of the board of arbitrators to whom the matter was referred might be rendered permanent matters of record, these arbitrators (or "commissioners to take testimony" as the act of Wisconsin denominated them) were required to report their proceedings from time to time to the District Court. If the partition of these lands had been through the agency of those persons mutually chosen by the parties interested, this would have been the act of the parties themselves; but the general partition law of Iowa Territory gave to the District Court.

\footnotetext{
"These chiefs whose names are marked thus were principal men selected by their nation to make the treaty at Washington on 4 th August, 1824, with others and were present on that occasion.
} 
no jurisdiction over this Indian reservation. Congress has expressly reserved this jurisdiction to itself and the act of Congress relinquishing the reversionary interest of the Government therein to the half-breeds was no surrender of jurisdiction to the Territorial authorities-neither did the treaty of 1832 give any jurisdiction to the Territory over this land; 1st, because it is not within the boundaries described in that treaty-and secondly, if it had been included within the limits, the Indians did not sell it, having reserved it from sale for the use of their half-breeds in 1824. In some subsequent number we shall recur to this subject as connected with the opinion of the Supreme Court of Iowa in the case of Reid vs. Webster.

In comparing the plan suggested by our circular extract hereinafter copied with the compromise midnight decree of partition of the 8th of May, 1841, it cannot escape the observation of anyone that the concocters and manufacurers of that decree stole the original design of an amicable adjustment of this matter from our plan as suggested in the following extract-but their entire ignorance of the rightful owners and of the means necessary to obtain that knowledge, together with their inherent villainy and desire of revenge and plunder, induced them at a late hour in the night after the adjournment of the court according to all ordinary rules in such cases, under circumstances of secrecy and most palpable collusion to manufacture a covinous and fraudulent division of the land among themselves, giving to the court itself a sweet morsel and laying a scheme to swindle the rightful owners out of all, unless they redeemed from Hugh $\mathrm{T}$. Reid, he being selected as holder of the stakes in this game of judicial gambling, from the fact that he had nothing to lose, but everything to win.

"With eyes so grey and hair so red,

With tusks so sharp and keen

Thou'lt fight the shades when thou art dead,

And hell won't let thee in."

Under what circumstances of deception this individual was recommended to our friends in St. Louis and in other places as an attorney or solicitor in chancery, we have never been able to ascertain-but this we do know, that he formed an early acquaintance with Ed. Johnson, Esq., and confiding in the integrity and capacity of this gentleman, we not only trusted much of our own business with him, but also recommended him to our friends, and that he formed a partnership with Reid in the practice of law, which proved his political death song.

We never contemplated a division of these lands without proof of ownership, but the utter ignorance of the parties to that decree was such that they could not prove their own claims, hence they 
made a virtue of necessity in admitting claims to all whom they either knew or presumed would co-operate with them. They. were in great haste to consumate their scheme-we were absent and in the State of Vermont at the time, and it was well, well known, not only to the Court but to its members and to the whole community, that we were both extensively interested in the lands, and thoroughly acquainted with many or all the circumstances of ownership therewith connected. It was therefore of the first [

promisers that this matter should be completed and the die cast prior to our return. To this end, therefore, a decree of partition of the whole property among a part of the rightful owners and a clan of pretenders was obtained. We together with many others were forever barred and concluded from all interest.in said property -and this too in the absence of proof on the part of the favored pretenders and directly in the face and against a host of evidence upon the public record in our favor. Why was this? We had become a troublesome customer to some and our interest was worth stealing. Our partners in New York had confided the management of their claims to D. W. Kilbourn whose first noted achievement after he left the great fire in New York was swearing falsely against James Thurmon-then against others in several instances-next purloining deeds, \&c., until he had given proof of his fidelity and talent in their service.

Many others had committed the care of their claims to Johnson and Reid, the former of whom having made an affidavit, (which the court in its great solicitude to get hold of the case admitted in lieu of the one required by law,) then retired from any further publicly known connexion with the business, leaving his partner to complete the scheme of villainy of which he was ashamed.

"On this conception Phoebus never smiled."

By this covinous decree of partition at least one million and a half of dollars was awarded-where there was not one cent in law or equity due. As we hope to invite investigation on this subject, and whether we succeed or not in that wish, we shall refer to it again; we shall close for the present.

We shall now examine the present condition of this estate in relation to its present and future prospects. For the last ten years the timber on this tract has been esteemed as common booty, and within that time more than fifty thousand dollars damage has been sustained by the owners of this property in the loss of its most valuable timber, and it is to be regretted that this system of plunder is still increasing-if the present state of things continue a few years more this beautiful tract of country will be stripped of all its valuable timber. The ineffectual efforts already made to quiet 
the titles to this property has only confirmed public opinion in the absolute uncertainty of ever accomplishing this object. And distrust among the claimants themselves has excited a public apprehension that a compromise will never be effected and the consequent uncertainty of title has both repelled emigrants and invited trespassers.

It has already been suggested that the difficulties in relation to the ownership of this property still remain to be settled by the operations of law or by the action of the parties themselves. And first, of the operations of law, it would seem that we have had more than enough already.

Many had turned all their hopes of success to the late Act of Wisconsin legislature, believing that if the provisions of that law could be carried into effect, the numerous vexed questions which had long disturbed the titles to this estate would be fairly and finally'settled. The valid claimants ascertained and the land partitioned amongst them or sold and the proceeds divided under the direction of the District Court. But how disappointed have been the expectations of even the warmest friends to this measure. Every step that was taken to [ ] that law was obstructed by accum. ulating obstacles. It was urged that the legislature had no right to interfere-that the judiciary of the territory had exclusive and the sole jurisdiction of not only making up a judgment upon all those points of controversy but likewise the exclusive right of superintending the progress of every minutiae in the course of these investigations, together with many other objections which it is useless to enumerate. The law, therefore, being unavailing, not from any real defect therein, but from the squeamishness of some who were charged with its administration, it was thought best to repeal it and which has been done accordingly by the late legislative assembly of Iowa Territory. We are now told that the late legislature of Iowa have enacted another law under the title of a general partition law which is intended to afford the desired relief. So far as I am capable of judging it is infinitely inferior to the one repealed and possesses no adaption whatever to the case in question, unless the presumption can be established that the owners of the Half-Breed Lands are Infants, Idiots and Lunatics, and in that event the law is a good one. provided the friends of the non-compas are pleased with the judge of the District Court is his super-added relation as Guardian.

I am fully persuaded that if any law now existing in the territory, or any law hereafter to be enacted, with every possible fitness to the subject, was attempted to enforce the adjustment of the present difficulties it would result in consuming more than the whole estate is worth in court charges, attorneys' fees etc. Many who had commenced their legal career with the strongest probabilities of success would be 
disappointed; while others, who were almost despairing at the outset, would find themselves to be the successful party, but not until they have paid well the second time for their property, or being unable so to do, those who had fought the battle must take the spoil.

We might advert to the lawless character of that extraordinary tax sale in December last as evidence that the existing authorities in this territory do not desire an adjustment of this matter advantageous to the present proprietors, but would rather lay the foundation for a new enterprise in the form of tax-titles. And if we may be permitted to infer, from the extraordinary character of their recent legislation in other matters we should not be disappointed if the next legislative assembly should declare the fee simple to be duly vested in such tax claimant. It is true that the tax sale alluded to is unconstitutional and unlawful in reference to the very law under which it was pretended to be sold. But if we are to be robbed, it is not because an effort for that purpose has been wanting. Another cloud is thrown over this already abstruse affair and the projectors of this new scheme of speculation doubtless contemplate security in the density of the cloud to which this pretended sale is designed to contribute. And now, after two years' legislating what has been accomplished? Instead of relief from our former troubles our embarassments have been increased and our property rendered almost worthless. Shall we suffer ourselves any longer to be thus inveigled by the fallacious pretensions of those, who, while they affect to assist us, will rifle our pockets and run away with the spoils? Or shall we abandon those golden notions which were conceived at an early period in the history of this operation and acting generously towards each other make such reasonable concessions to one another as may at least afford an indemnity to all? When we reflect on the almost endless litigations which must attend any course of judicial investigation, the appeals which inevitably will be taken from one court to another and the reversed decisions which may be anticipated with certainty, who that wishes to realize even a dollar from his investments in this property, can for a moment hesitate between the operations of the law and the compromising action of the parties themselves? Should we, however, continue to entertain such overweening notions of our own exclusive pretensions as to reject the proposed compromise, we must not be disappointed if we entail to our posterity a fruitful source of lawsuits and ruin. In conclusion, we will next inquire what the parties can do for themselves.

Surrounded as this affair has been with such a mass of accumulated embarassments I should long since have abandoned it as a hopeless case, but I have always been accustomed to confide in the people themselves and I still believe they will act prudently 
and wisely as soon as they can act understandingly. The first step necessarily to be taken in order to effect a union and concert of action among the whole body of claimants will be for those who have regarded themselves exclusive owners of this property to pare down their extravagant expectations and abandoning these golden dreams act justly and generously towards those claimants whose pretensions they have been disposed to disallow. A union upon equitable terms to all the parties interested may be regarded as advantageous as much to one class of claimants as to another. Bur it is urged by some that this plan of admitting the claims of all who have a fair appearance of title upon the public records we shall greatly diminish the quantity of land to which each individual will be entitled. This is true, but is it an easy matter to determine who are the losers? If we can readily ascertain this point, our object is already attained; we need proceed no further. This question would again involve the reconsideration of the entire subject and leave us where we began. If indeed the quantity of land to which each individual may be entitled should be hereby diminished, it is equally true that this disadvantage will be more thar: counterbalanced by the increased value of the property arising from the security of the titles and the severality of the ownership. This property has never been esteemed as valuable at any other period of its history as it was in the summer of 1837 , when an effort similar in its general character to the one now contemplated, was at tempted and might have succeeded had it been encumbered with fewer heads and less jealousy. I hope to be excused for saying that I have always attributed the failure of that effort in a great measure to the circumstances of having committed the management of these affairs to persons unacquainted with the local difficulties which incumbered the subject. And those gentlemen with whom I have endeavored to act at that time will do me the justice to say that it was with extreme reluctance that I relinquished the scheme of a compromise for a resort to legislation. This property has been rapidly depreciating in value during the last two years; hence the interests of all parties concerned as well as the peace of society and prosperity of that valuable section of the territory require that those causes of disquietude should be speedily and efficiently removed.

\section{NUMBER THREE.}

Authorized by the treaty and act of Congress, recited in our first number of this history, many individuals were encouraged to purchase from half-breed Indians their presumed shares or portions in this reservation and from 1834 to 1837 public attention was more or less directed to these lands as a field of speculation. Several gentlemen in Sţ. Louis, Mo., vested considerable sums of money in 
these lands and within the period of time above suggested, small parcels of undivided interest in this tract of land was owned by individuals in Canada, New York, Pennsylvania, Delaware, Mississippi, etc. We had made a purchase of an equal undivided half of the portion of Mary Duque, a half-breed Fox woman who resided in our family and who had married one of our clerks, a white man named Tolman. This contract was made in the autumn of 1829 . In the spring of 1830 we erected the necessary tenements and put under cultivation 40 acres of land in what is now called "Sand Prairie," on the river Des Moines, now occupied by S. Hearn. Upon this farm was placed the above named Tolman and wife with stock amounting to one thousand dollars, including the expense of making the farm. This was the consideration given for the first half portion of undivided interest in this reservation which was sold by a half-breed. As the first sales of almost any property brought into market are generally regarded as data from which to regulate subsequent sales and purchases, we had viewed this circumstance, though trivial in itself, yet not altogether undeserving of notice here.

Hence, it will be observed that in the first purchase ever made of interest in this reservation it was estimated at two thousand dollars a share or portion. Still, however, many of the half-breeds had formed a much higher estimate of these lands; their prices ranging from two to twenty thousand dollars a share. There were two contingencies which were calculated to produce this great disparity in the estimated value of these shares.

First, it was contended that this land was given by the Indians to the civilized half-breeds belonging to their nation and to none other. This rule, under the provisions of the act of Congress before referred to, would probably reduce the number of original reserves to not exceeding thirty. In opposition to this it was urged that all halfbreeds, including more than a hundred, were equally entitled.

And, secondly, it was contended by some that the reservation contained more than two hundred and thirty thousand acres of land, if the north boundary was run where the treaty called for. Whilst others insisted that the present line was too far north already and that the tract should be greatly reduced from its present contents. Hence; a purchaser could not determine whether he was acquiring by his purchase of one share a hundred acres or five thousand acres.

As we had settled upon this reservation and felt an interest in the title which the government might grant as well as a correct understanding of its boundaries and extent, we carefully examined first the north boundary of the state of Missouri as established by law.*

\footnotetext{
*Laws establishing the Boundaries of the State of Missouri, passed the 12 th day of June, 1820 .
} 
"We do declare, establish, ratify and confirm the following as the permanent boundaries of said state, that is to say: Beginning in the middle of the Mississippi river, on the parallel of thirty-six degrees north latitude; thence west along the said parallel of latitude to the St. Francois river; thence up, and following the course of that river in the middle of the main channel thereof to the parallel of latitude of thirty-six degrees and thirty minutes; thence west along the same to a point where the said parallel is intersected by a meridian line passing through the middle of the mouth of the Kansas river, where the same empties into the Missouri river; thence from the point aforesaid north along the said meridian line to the intersection of the parallel of latitude which passes through the rapids of the river Des Moines, making the said line correspond with the Indian boundary line; thence east from the point of intersection of the parallel of latitude to the middle of the channel of the main fork of the said river Des Moines; thence down along the middle of the main channel of the said river Des Moines to the mouth of the same, where it empties into the Mississippi river; thence down and following the course of the Mississippi river in the middle of the main channel thereof to the place of beginning."

We then carefully compared this with the following treaty:*

"The Sacs and Fox tribes or nations of Indians by their deputations in council assembled do hereby agree in consideration of certain sums of money, etc., to be paid to said Sacs and Fox tribes by the government of the United States, as hereinafter stipulated, to cede and forever quit claim and do in behalf of their said tribes or nations hereby cede, relinquish and forever quit claim unto the United States all right, title, interest and claim to the lands which the said Sacs and Fox tribes have, or claim, within the limits of the state of Missouri, which are situated, lying and being between the Mississippi and Missouri rivers, and a line running from the Missouri at the entrance of Kansas river, north one hundred miles to the northwest corner of the state of Missouri, and from thence east to the Mississippi. It being understood that the small tract of land lying between the rivers Des Moines and the Mississippi and the section of the above line between the Mississippi and the Des Moines, is intended for the use of the half-breeds belonging to the Sacs and Fox nations; they holding it, however, by the same title and in the same manner that other Indian titles are held."

From these authorities we formed our views of the boundaries and extent of this reservation. But very different constructions have been put upon these seemingly clear public documents.

\footnotetext{
* Treaty between the United States and the Sacs and Fox Tribes or Nations of Indians entered into August $4 \mathrm{th}, 1824$.
} 
This difference of opinion we have always believed originated in selflsh and interested motives which afterwards drew into its vortex many honest and well disposed individuals, until the authorities of Missouri and Wisconsin and afterwards Iowa got into difficulties on this subject. Missouri claimed the right to run and establish her northern boundary from a point where the meridian which passes through the middle of the mouth of the Kansas river where the same empties into the Missouri river, intersects the parallel of latitude which passes through the rapids of the river Des Moines; "thence east from the point of intersection last afore. said, along the said parallel of latitude to the middle of the channel of the main fork of the said river Des Moines." But our wise ones most logically contended that "the said river Des Moines" was according to the peculiar idiom of the French language, neither more nor less than the Mississippi river!! Hence, Missouri must run her northern boundary on a parallel of latitude with the rapids in the Mississippi. This maneuver, with all its imbecility and injustice. was urged before Congress and the motive was clearly apparent, when a multitude of land sharks rushed down upon the "Sauk and Fox half-breed tract" to make their "tomahawk improvements," declaring it was Congress land and that they were "pre-emptors," etc. And still to make their intentions appear more plausible and to divert public attention from their real motive, a great military campaign was got up against the northern frontiers of Missouri, and another Wolverine war was got up, much like that of ohio and Michigan. But while our brave troops were keeping vigil on a tentless plain, near the contemplated field of blood, some gentle sibyl kindly whispered in the sleeping ear of our brave commandant:

"Dost thou then sleep great monarch of the woods;

The fawns are rustling near thee."

The army of invading occupation soon retraced their steps and were all safe at home on their own side of the Des Moines river the next day. Still a belligerent attitude has been kept up towards Missouri-her land marks have been demolished by some persons, who probably presumed that such circumstance would either support the peculiar idiom of the French language before alluded to, or move the rapids of the said river Des Moines to a more southern latitude.

It will be observed that an extension of the north boundary of Missouri from "the rapids of the said river Des Moines" to the Mississippi river to a point on the same parallel of latitude is the northern boundary of this reservation if there is any sense or mean. ing in either the French or English language. And our learned critics have understood it so, except perhaps one, who has assumed that the north boundary of this reservation is fixed, let the north boundary of Missouri hereafter go where it may-whether this 
decision is predicated upon some idiom of French, Indian or English language, we are not informed.

But we do know that by a paramount law of the United States that section of an extension of the north boundary of Missouri which would be between the rivers Des Moines and Mississippi is declared to be the north boundary of this reservation.

\section{NUMBER FOUR.}

We close our third number of this article with a passing notice of some of the efforts used by demagogues and swindlers to rob Missouri of a part of her territory, and at the same time to cheat the half-breeds and their venders out of the greatest portion of their reservation.

We will here advert to a circumstance of vital importance on this subject, which the State of Missouri will doubtless not lose sight of, in the adjudication of her boundary question.

Col. Jno. W. Johnson of St. Louis, Mo., was present at Washington on the 4th of August, 1824, when the treaty granting this tract to their half-breeds was made by the Sac and Fox Indians; from whose letter we made the following extract:

"Dear Sir:-I have this day received the third number of your little paper, (Iowa Advocate) and believe it may be of great service to the true owners of the halfbreed lands; I say the true owners, because I know their number did not exceed thirty-eight, including St. John's children. And the list of names made out by the same Chiefs who made the treaty and gave the land, designated them by name to Mr. Forsythe, their Agent. I also believe it was the intention of those Chiefs that the termination of the northern line of Missouri, where it strikes the river Des Moines, should be the beginning point for the half-breed tract. At the treaty of the 4th of August, 1824, at Washington city, in order that, and for fear of being misunderstood, the Chiefs marked with coal the river Des Moines and Mississippi on a piece of plank, which was presented by them at that council or treaty, showing the situation of the land they were then giving to their half-breed relations-I also knew it from the Chiefs themselves. And when the northern boundary of Missouri is established the half-breed claimants should insist on their rights-as it now is, they are deprived of one-half of their rights; and the United States having sold their lands should pay them for it. Still that fraudulent decree claim a participation in this additional land if recovered. At this treaty the Chiefs and head men of the Sac and Fox Indians, urged strongly on the Commissioner on the part of the United States, to consent that the half-breeds might have a strip of land ten miles wide and extending from the Mississippi to the Missouri river-the Indians in- 
sisted on this proposition, alleging that it would be a means of se curing peace and good feeling between the two races, to have the half-breeds settle on the northern frontier of Missouri, between the white people and the Indians-but the proposition being overruled by the Government Agents, it was finally agreed that the halfbreeds should have the tract described in the treaty.

This circumstance shows conclusively that the Sac and Fox Chiefs intended to make a liberal bequest to their half-breed relationsthey owned a vast territory containing many millions of acres, of which they desired to give their half-breeds about one million and a half, but being prevented from doing this by the interference of the Commissioner, they finally succeeded, as they supposed, in granting them about two hundred fifty thousand acres-but this again was curtailed to a little more than one hundred thousand acres; then a war was got up against the State of Missouri with a view of seizing upon a little more than half of what still remained.

Next the territorial Legislature, in order to make smooth work of it, had the whole tract sold in mass for taxes-but fearing that the work was, not yet quite finished, they sent two of their friends, who happened to be out of employment, to sit at Montrose, etc., at the modest salary of $\$ 6.00$ each per day-and after sitting a whole summer, without any evidence of incubation, the Legislation next passed the golden egg to the care of the District Court, with a special injunction that a vulgar jury should not be permitted to handle the delicate charge-here this matter was permitted to rest, until another movement could be made upon the judicial chess-board.

The whole history of this judgment title as it is called, will be found in the reported trial of Reid vs. Webster, and the opinion of the Supreme Court of the Territory of Iowa in that case, which will be found in this paper.* And to which, therefore, we refer our readers as a part of our present number on the history of this tract.

[Following is the syllabus of Reid vs. Webster--Ed. ANNALs]:

The treaty of 1824 , with the Sac and Fox tribes of Indians, by which certain lands were ceded to the United States, did not include that portion of their lands lying between the rivers Desmoines and Missis. ippl, which was reserved for the half breeds, belonging to said tribes.

By this treaty of 1824 , the half breeds had conferred upon them the right of private property in the lands reserved for their use, and not the sovreignty over them.

The title of the half breeds was not disturbed by the second treaty and cession in 1832, as the cession of lands from one nation to another, does not effect the right of private property.

The act of Congress of June 30,1834 , conferred upon the half breeds of the Sac and Fox tribes, a full fee simple title as tenants in common, to the reserved lands lying in Lee county, Iowa.

*See Webster vs. Reid, Morris' Iowa Reports, p. 467. 
Although a legisiature has not the power to destroy vested rights, it can create or augment them.

If a legislature sees proper to violate the solemn stipulations of a treaty there is no power in the judicary to prevent it.

If a treaty is by the constitution declared to be the supreme law of the land, so is an act of Congress. The latter may repeal the former, in the same manner that one statute may repeal another.

After the act of Congress of 1834, the half breed tract was to the fullest extent individual property, and as such, by the Organic Act, placed under the municipal regulations of the territory of Iowa.

The act of 1834 , conferring on the half breeds a title, is a public statute, and should be judicially noticed.

A party to a judgment cannot collaterally impeach it for fraud, much less can a stranger be permitted thus to do it.

As a general rule, a judgment at law is an act so far conclusive, as not to be disturbed by another judgment at law.

A contract however fraudulent, is not a nullity; it is valid as to all the parties to the fraud, and to all others except those who are injured thereby.

Judgments rendered under an unconstitutional law are not nullities; and a sheriff levying and selling under such a judgment would not be a trespasser.

\section{COPY OF RESOLUTIONS}

Adopted at the meeting of the County Board of Callaway county, Missouri, at their meeting, July 23, 1862.

Resolved, That we condemn the policy. pursued by weakbacked Union men of this county, in lending the weight of their influence, in signing petitions, misrepresenting facts, for the purpose of securing pardons for, and thereby turning loose upon the community, characters who have been guilty of the most outrageous crime and outrages against this com. munity and their Government.

Resolved, That the action of such persnus clearly "actively aid the rebellion," and that our duty will compel us to place their names on the Assessment Roll of this county.

Geo. Duffield, Capt. 3d I. C.

Joshua J. P. JoHNSON, JoHN S. WiLliams.

Fulton, Mo., Missouri Telegraph, July 2, 1862. 
Copyright of Annals of Iowa is the property of State of Iowa, by \& through the State Historical Society of Iowa and its content may not be copied or emailed to multiple sites or posted to a listserv without the copyright holder's express written permission. However, users may print, download, or email articles for individual use. 